\title{
Indian-Atlantic subsurface- and deep- water mass exchange over the past 600 kyrs
}

\author{
JOSE N. PEREZ-ASENSIO ${ }^{1}$, KAZUYO TACHIKAWA ${ }^{1}$, \\ LAURENCE VIDAL $^{1}$, THIBAULT DE GARIDEL-THORON ${ }^{1}$, \\ CORINNE SONZOGNI ${ }^{1}$, ABEL GUIHOU ${ }^{2}$, PIERRE \\ DESCHAMPS $^{1}$, STEPHAN JORRY ${ }^{3}$ AND MIN-TE CHEN ${ }^{4}$ \\ ${ }^{1}$ Aix Marseille Univ, CNRS, IRD, INRAE, Coll France, \\ CEREGE \\ ${ }^{2}$ CEREGE, Aix Marseille Univ, CNRS, IRD, INRAE, Coll \\ France \\ ${ }^{3}$ Ifremer Brest \\ ${ }^{4}$ Institute of Earth Sciences, National Taiwan Ocean University \\ Presenting Author: perez@cerege.fr
}

The water-mass exchange between Indian and Atlantic oceans, occurring through Agulhas current and its leakage, is one of the return flows of global thermohaline circulation. To investigate the Indian-Atlantic subsurface- and deep-water mass exchange over the last $600 \mathrm{kyrs}$, we analyzed $\mathrm{Nd}$ isotopic composition $\left(\varepsilon_{\mathrm{Nd}}\right)$ on planktic foraminiferal authigenic fraction, epibenthic foraminiferal stable carbon isotopes $\left(\delta^{13} \mathrm{C}\right)$, and planktic foraminiferal warm species in the sediment core MD96-2077 (SW Indian Ocean, 3,781 m). At present, this sedimentary sequence is bathed by modified Circumpolar Deep Water and it is below the flow path of the Agulhas current. The obtained $\varepsilon_{\mathrm{Nd}}$ and $\delta^{13} \mathrm{C}$ records show glacial/interglacial variability ranging between -8.0 and -10.3 , and between -1.1 and $0.7 \%$, respectively, with higher $\varepsilon_{\mathrm{Nd}}$ values coinciding with more depleted $\delta^{13} \mathrm{C}$ values and vice versa. Planktic warm species relative abundances vary from 1.2 to $37.6 \%$ with a marked increase during terminations. The most striking feature of our record is systematic very low glacial $\delta^{13} \mathrm{C}$ values similar to records from the deep SE Atlantic (ODP Site 1090). Relationship between $\varepsilon_{\mathrm{Nd}}$ and $\delta^{13} \mathrm{C}$ of the studied core compared with existing records indicates similar trends with deep SE Atlantic water masses, suggesting that deep glacial carbon-rich water extended from the SE Atlantic into the SW Indian Ocean. Contribution of Indian deep water cannot account for the low benthic $\delta^{13} \mathrm{C}$ values observed at the study site. The increases in warm planktic species relative abundances during the terminations are coincident with reconstructed Agulhas leakage peaks, suggesting a possible link between Agulhas current and Agulhas leakage during terminations. To better constrain the deep-water variability of the northern and southern source water masses arriving at the SW Indian Ocean, we are analyzing the foraminiferal $\varepsilon_{\mathrm{Nd}}$ in core MD96-2052 (2,627 $\mathrm{m}$ water depth) from the Mozambique Channel. This core is currently occupied by North Atlantic Deep Water (NADW) as confirmed by an $\varepsilon_{\mathrm{Nd}}$ value of -11.7 in the core-top sample, in the range expected from present-day NADW. Based on this new record, we will investigate the changes in northern and southern source waters together with subsurface water conditions. 